\title{
Generating Electricity Using Geothermal Energy in Iran
}

\author{
Armin Ramezani, Mohammad Vahedi Torshizi, Arash Attari and Farhad Tabarsa \\ Department of Bio-System Mechanical Engineering, Gorgan University of Agricultural Sciences and Natural \\ Resources, Gorgan, Iran. \\ mohammadvahedi4130@gmail.com, \\ armin.Ramzani@yahoo.com, arashattari1995@gmail.com, \\ farhadtabarsa75@gmail.com
}

\begin{abstract}
Given that fossil fuels will end one day and that these types of fuels produce a lot of pollution, each country should look for new ways to generate energy that is needed for its people in proportion to its energy resources. Given that Iran is geographically located in an appropriate region of the earth, it has a great potential for using renewable energy. In this study, sources and uses of Iranians' geothermal energy have been studied, all of which indicate that Iran has a very good potential for electricity production using geothermal energy. According to the information gathered, Iran has one geothermal energy plant in Meshkin shahr city and this plant power with a capacity of 100 megawatts is an active power plant in Iran. Also, the potential of geothermal power generation was verified in Khoy located in Azarbaijan Gharbi province, Sabalan Ardebil province, Sahand in Azarbaijan Sharghi and Damavand in Tehran province Examination verified that around $8.8 \%$ of total land in Iran is capable of geothermal energy production.
\end{abstract}

Keywords - Iran, Geothermal Energy, fossil fuels, renewable energy.

\section{INTRODUCTION}

Iran (Islamic Republic of Iran) is located in the West Asia, surrounded by Caspian Sea, Azerbaijan, Turkmenistan, Armenia, Pakistan, Afghanistan, Iraq, Persian Gulf, Oman Gulf and Turkey [1]. Total area of this country is 1.65 million $\mathrm{km} 2$, and its population is about 80 million people including $49.6 \%$ females and $50.6 \%$ males. Iran has a warm and dry climate by long summers and short, cold winters[2] [3]. The same climate and the four seasons have led to a special look at using renewable energy in sustainable development in different fields. Statistics showed that Iran has the fourth largest crude oil reserves, the second largest natural gas reserves in the world [4], and a very high potential in renewable energy sectors, such as solar, wind, geothermal, etc. which can be used exclusively in any of the cities in Iran [5].

On the one hand, energy plays a significant role in the economic and social activities of the humans and the country and the growth of energy and its use and productivity will also lead to the welfare of people. Hence, over the past years, great attention has been paid to energy production in a variety of ways [6]. On the other hand, fossil fuels have been used extensively in the past two decades and fossil resources are limited and one day they will end. So any country should know the energy available in it and also lookto create new ways to produce energy[7]. Also Iran has a lot of fossil resources, which could be easily used for many years, but the point to consider is, how long can these fuels be used? Figure 1 shows the use of renewable energy in seven countries, which is the largest amount of wind power use for china and the largest use of solar energy in Germany [8]. 


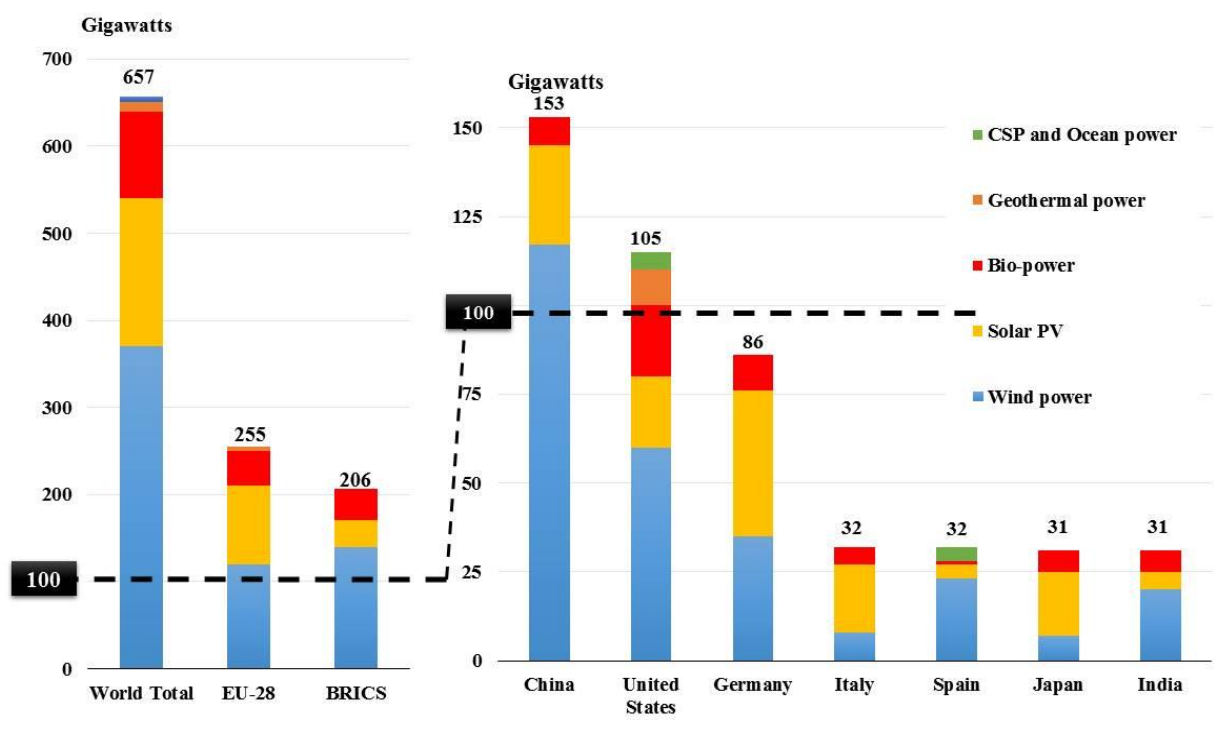

Fig.1. Renewable power capacities in the word, eu-28, brics, and top seven countries

In recent years, the consumption of fossil fuels in Iran and the world has multiplied [9]. In addition, the rising cost of fossil fuels and their damaging environmental impacts, such as pollution, rising ground temperatures, and ozone depletion, have increased the desire to use renewable energies [10][11].

The large oil and gas producers Iran is the world's $7^{\text {th }}$ largest emitters of $\mathrm{CO}_{2}$ from Fossil Fuels. The diagrams below show the per capita $\mathrm{CO}_{2}$ emissions from Fossil Fuels (without bunkers) and cement, annually since 2000. The green bars show the free emission level - the exceedance is the basis for calculating the national Climate Debt. Iran was responsible for $1.9 \%$ of global emissions in 2015 .

Also Iran has the highest share of $36.15 \%$ of greenhouse gas emissions in the Middle East, and next to Iran are Saudi Arabia and United Arab emirates which are also ranked $24.29 \%$ and $14.9 \%$, respectively. The use of energy carriers, with the production of pollutant and greenhouse gases in the conversion process and causing more warming of ground and climates in the destruction of the ozone layer, put the environment seriously in the face of the threat [12] [13]. Figure 2 shows the contribution of different sectors to greenhouse gas emissions [14].

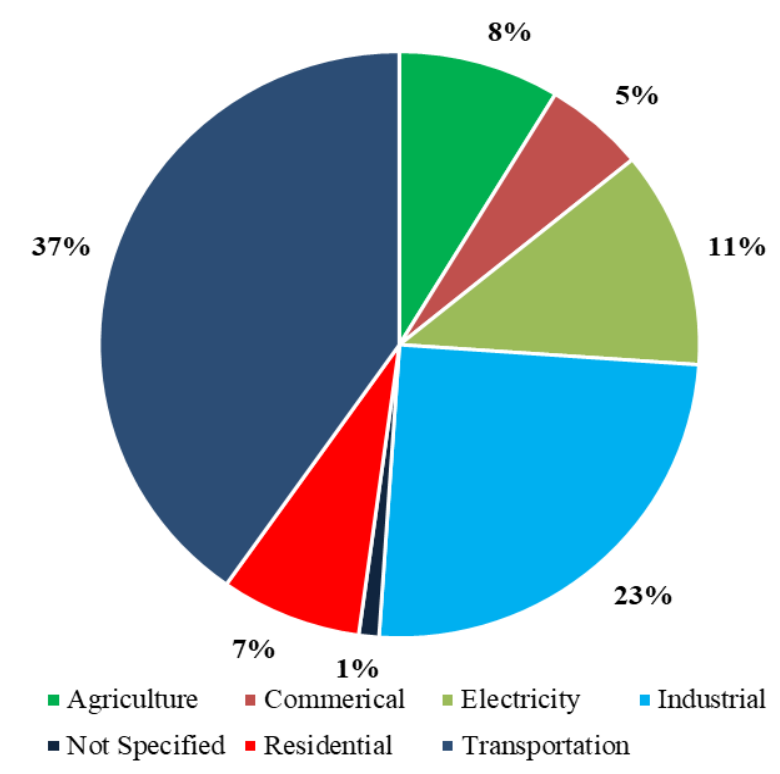

Fig. 2. Green House Gas Emissions by Sector 
Today, the challenge of energy policies is to reduce fossil fuel production and environmental costs. Since the expansion of access to energy (heat, light, etc.) is very important in developing countries [15] and various political and other measures have been taken to reduce energy consumption, renewable energy is introduced to solve this problem and high productivity of renewable energy and the transfer of clean technologies are considered in different countries,. Given the fact that in the last century there has been a significant growth of energy consumption in the world, meeting the energy needs of humans has been considered as well as the major role fossil fuels play in supplying this energy [16] [17].

Also Iran has abundant resources in fossil fuels. Proven oil reserves include gas liquids of more than 137 billion barrels, accounting for 11 percent of the world's resources while natural gas resources are more than 26.7 trillion cubic meters or $15 \%$ of the world's total resources [18]. Figure 3 shows the production of fossil fuels for Iran [19] .

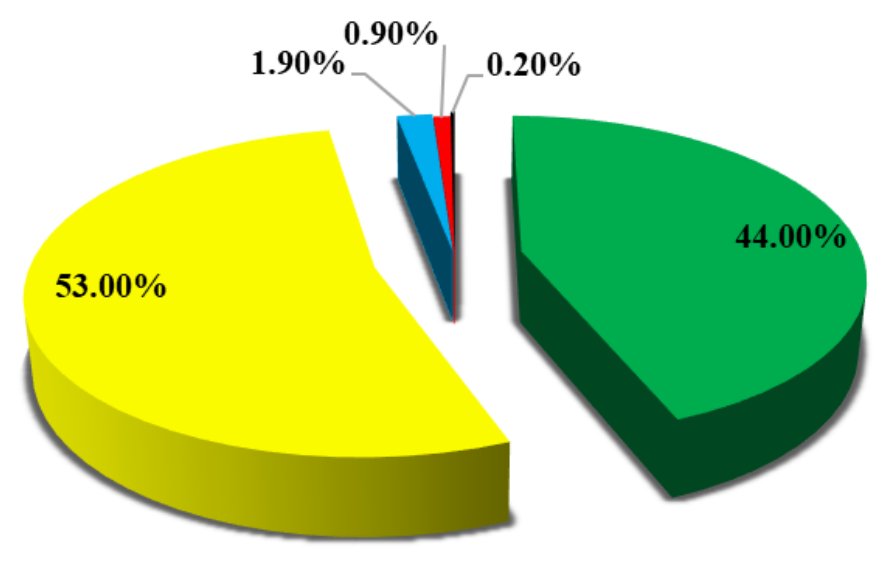

¿ Oil Natural Gas $\square$ Hydroelectric power $\quad$ Coal $\square$ Non commerical

Fig. 3. Production of fossil fuels in Iran

It is a well-known fact that Iran's economy is a mixed economy where the government companies own oil and the other large companies agriculture and investment services. Given the diversity of the Iranian economy, Iran's economy is still heavily dependent on oil exports. At present, oil exports account for $80 \%$ of total exports which accounts for nearly 50 percent of the government's budget and is 23 percent of the gross domestic product. With growing demand for energy, increased environmental pollution, and depleting energy sources, human society today faces multiple challenges of transition towards sustainable development and poverty eradication [20] .In 2005, 2713.4 million tons of carbon dioxide emissions from burning of combustible fuels have been released in the world. The 1671.7 million tons equivalent to greenhouse gas (CO2) emissions in the Middle East region have been released and 1,238.1 million tons of this gas were due to the burning of combustible fuels [21].

the total new global investments in renewable energy increased from $\$ 40$ billion in 2004 to $\$ 244$ billion in 2012 [22]. According to the International Energy Agency, utilization of renewable energy will triple between 2008 and 2035. Also, it is anticipated that the share in renewable electricity production in the middle eastern regions, the heart of the world's fossil fuel reserve, will amount to $16 \%$ in 2035 [6]. 
Table 1. Lists of Power Plants with Fossil Fuels in Different Parts of the Country

\begin{tabular}{|c|c|c|c|c|c|}
\hline \multicolumn{2}{|c|}{$\begin{array}{l}\text { Power plants with capacity of } 1 \mathrm{MW} \\
\text { And less }\end{array}$} & \multicolumn{2}{|c|}{$\begin{array}{c}\text { Power plants with a capacity of more } \\
\text { than } 1 \mathrm{MW}\end{array}$} & \multirow[t]{2}{*}{ Province name } & \multirow[t]{2}{*}{ Rating } \\
\hline Capacity (MW) & Number & Capacity (MW) & Number & & \\
\hline $662 ?$ & 110 & 131 & 8 & Khoracan razavi & 1 \\
\hline 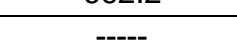 & ---- & 16.85 & 5 & Kohkelove va bover ahmad & 2 \\
\hline 317 & 21 & 14.46 & 4 & Esfehan & 3 \\
\hline----- & ----- & 102.52 & 4 & Zanjan & 4 \\
\hline 32.84 & 5 & 9.843 & 6 & Tehran & 5 \\
\hline 100 & 1 & 19.61 & 5 & Markazi & 6 \\
\hline $\begin{array}{l}---- \\
\end{array}$ & $\begin{array}{l}---- \\
\end{array}$ & 11.2 & 3 & Kerman & 7 \\
\hline 66 & 2 & 13.975 & 4 & Fars & 8 \\
\hline ----- & ----- & 18.66 & 3 & Khuzestan & 9 \\
\hline---- & ----- & 53.78 & 2 & Gilan & 10 \\
\hline 169 & 18 & $\begin{array}{ll}---- \\
\end{array}$ & $\begin{array}{ll}---- \\
-1\end{array}$ & Kerman & 11 \\
\hline 160 & 4 & 4 & 1 & Yazd & 12 \\
\hline ---- & ----- & 3.96 & 4 & Azarbayjan sharghi & 13 \\
\hline 155 & 12 & ---- & ----- & Khorasan jonobi & 14 \\
\hline 1.2 & 1 & 1 & 1 & Mazandaran & 15 \\
\hline ----- & ----- & 10 & 1 & Kermanshah & 16 \\
\hline $\begin{array}{l}---- \\
\end{array}$ & $\begin{array}{l}---- \\
\end{array}$ & 6 & 1 & Azarbayjan gharbi & 17 \\
\hline $\begin{array}{ll}---- \\
\end{array}$ & ----- & 10 & 1 & Kordestan & 18 \\
\hline ----- & ----- & 5 & 1 & Chaharmah bakhtiyari & 19 \\
\hline ----- & ----- & 2.8 & 1 & Hamedan & 20 \\
\hline 50 & 7 & ----- & $\begin{array}{ll}--- \\
\end{array}$ & Ghazvin & 21 \\
\hline 15 & 3 & ----- & ----- & Semnan & 22 \\
\hline ----- & ----- & 1.6 & 2 & Lorestan & 23 \\
\hline ----- & ----- & 0.66 & 1 & Sistan va balochestan & 24 \\
\hline 2.5 & 1 & ----- & ----- & Boohsher & 25 \\
\hline 5 & 1 & ----- & ----- & Hormozgan & 26 \\
\hline
\end{tabular}

Geothermal energy is one of the renewable energy resources witnessing increasing interest. It can supply energy demand in two different forms. It could be used indirectly for geothermal power generation or be utilized directly for heating purposes such as greenhouses, district heating, fish farming and others [23].

82 countries around the world have reported installing direct use of geothermal applications. Some of these countries have a long history in the research and development of direct geothermal energy use. Amongst these countries are: the US, Iceland, and New Zealand. In the case of the US, the direct utilization of geothermal energy includes heating of swimming pools and spas, aquaculture and greenhouses, district heating, industrial applications and ground-source heat pumps. The largest application is ground-source heat pumps accounting for $88 \%$ of the annual energy use. In summary, when considering direct-use without geothermal heat pumps, the distribution of annual energy use is as follows: $34 \%$ for fish farming, $28 \%$ for bathing and swimming, $15 \%$ of individual space heating, $9 \%$ for greenhouse heating, $9 \%$ for district heating, and the rest is for agricultural drying, industrial process heating, cooling, and snow melting. The current installed capacity and annual energy use for district heating is $81.55 \mathrm{MW} /$ th and $839.6 \mathrm{TJ} / \mathrm{yr}$ [23] [24].

Iran has a high geothermal energy potential. The country geothermal gradient range varies from $2^{\circ} \mathrm{C} / 100 \mathrm{~m}$ in the Zagros belt to $13^{\circ} \mathrm{C} / 100 \mathrm{~m}$ around the Damavand volcano in the north. Most geothermal energy studies in Iran have focused on electricity production, while, research on the direct use of geothermal energy have received less attention [25] [26]. 
The result indicated that $8.8 \%$ of land area in Iran has geothermal potential with 18 promising hightemperature geothermal fields. These eighteen prospected areas have been recommended for detailed geological, geochemical and geophysical investigations. The most investigated field in Iran is the Sabalan geothermal prospect. Sabalan lies in the Moeil valley on the western slopes of Mt. Sabalan, approximately $16 \mathrm{~km}$ southeast of the Meshkin-Shahr city. Eleven wells including 7 productions, 1 reinjection, and 3 monitoring wells have been drilled in Sabalan, which is recognized as a potential for geothermal power generation [27].

\section{GEOTHERMAL ENERGY}

\section{What is Geothermal Energy?}

Geothermal energy is one of renewable energy sources. Geothermal is a Greek term and is composed of two words; geo which means earth and thermal which means heating. Geothermal energy is the energy available in the depths of the earth. It is created from solar energy that has been stored inside the earth for thousands of years [7]. Also, the collapse or decay of radioactive uranium, thorium and potassium in earth originated in a long depth mainly in areas prone to earthquakes, volcanic young and tectonic plates of earth focused. The earth's heat is driven from parts of the earth in a variety of ways, including volcanic eruptions - water springs, ocean springs and golfers, due to the reduced density of the earth and the conductivity [28].Geothermal energy, unlike other renewable energies, is not limited to season, time, and conditions and cannot be exploited without interruption. Also, the cost of electricity in geothermal power plants is compatible with other conventional fossil fuels and it is even cheaper than other types of renewable energy [29]. Figure 4 shows a schematic of a geothermal power plant [30].

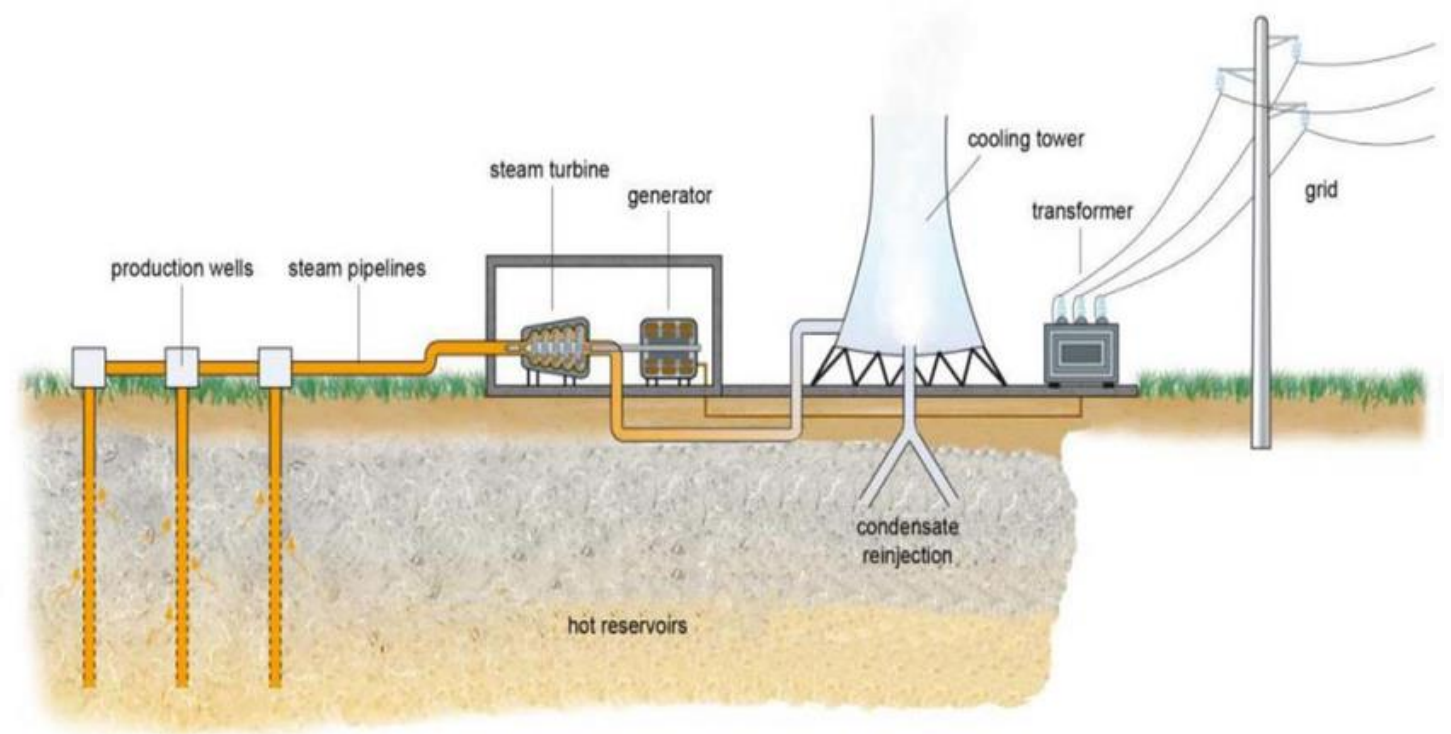

Fig. 4. Schematic of a geothermal power plant

Figure 5 shows the geothermal energy dispersion in the world indicating that the United States, Mexico and North America have more energy production [30]. 


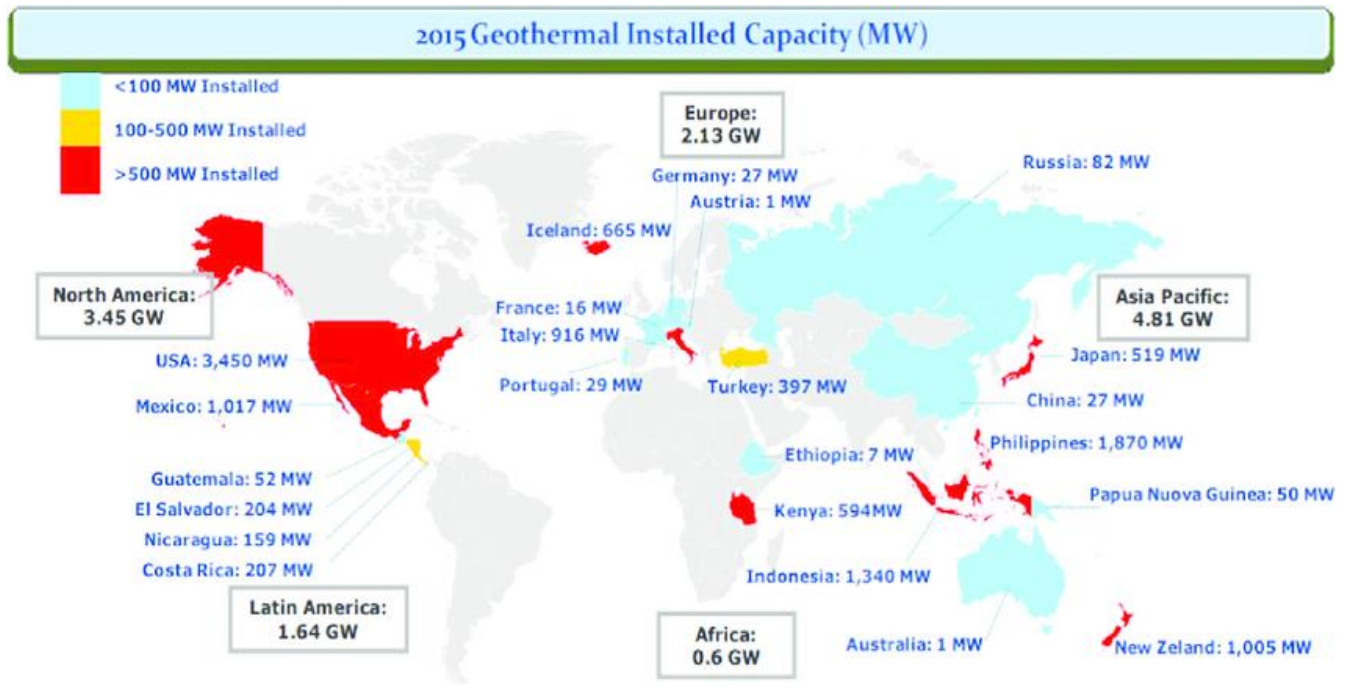

Fig. 5. Worldwide geothermal based electric power generation

\section{Environmental Benefits}

One of the most important advantages of using geothermal heat pumps is the reduction of environmental degradation effects given that heating systems work with fossil fuels and this kind of fuel is one of the main factors in the production of environmental pollutants. Replacing a variety of new energies instead of fossil fuel systems can significantly reduce greenhouse gas emissions and pollutants [31] [32].

Figure 6 shows the amount of $\mathrm{Co}_{2}$ production for thermal power plants with fossil fuels and renewable fuels [30]. It can be seen that geothermal power plants have a very low $\mathrm{CO}_{2}$ production rate compared to that of fossil fuels power plants, and the binary cycle produces very little $\mathrm{Co}_{2}$ [33] .

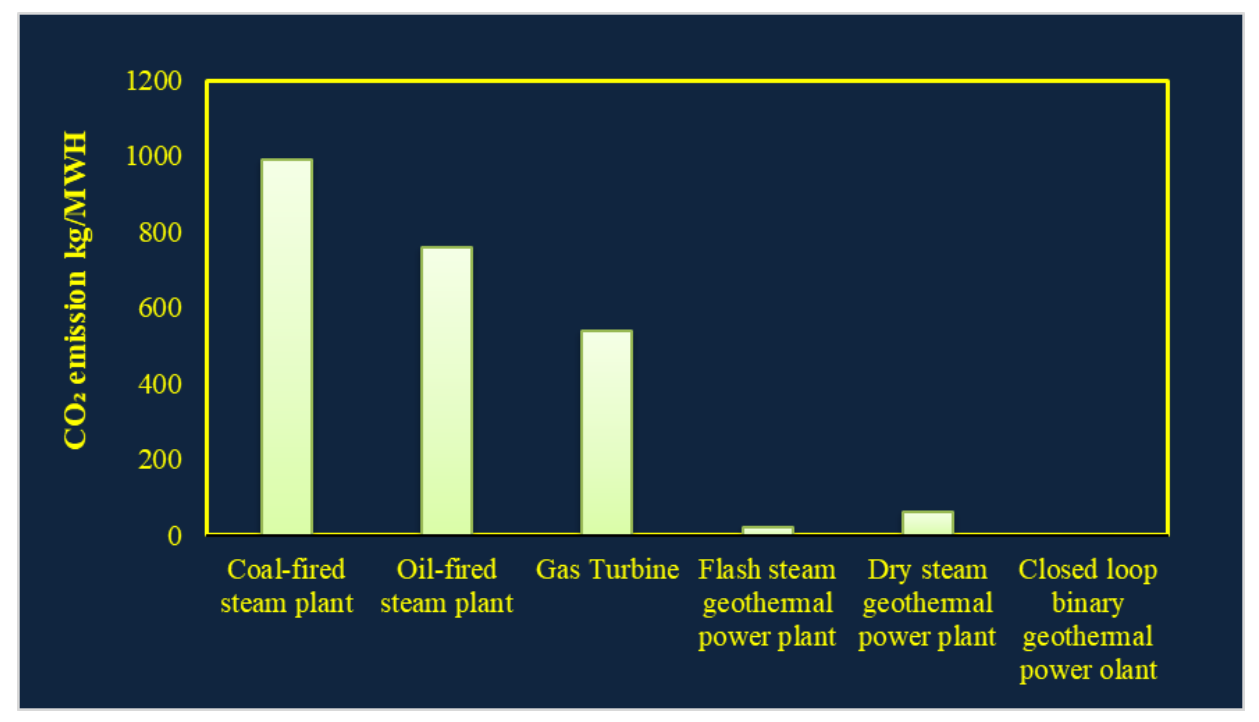

Fig. 6. CO2 emissions from various power plants

Also Figure 7 shows the geothermal energy use in different sectors from 1995 to 2015. 


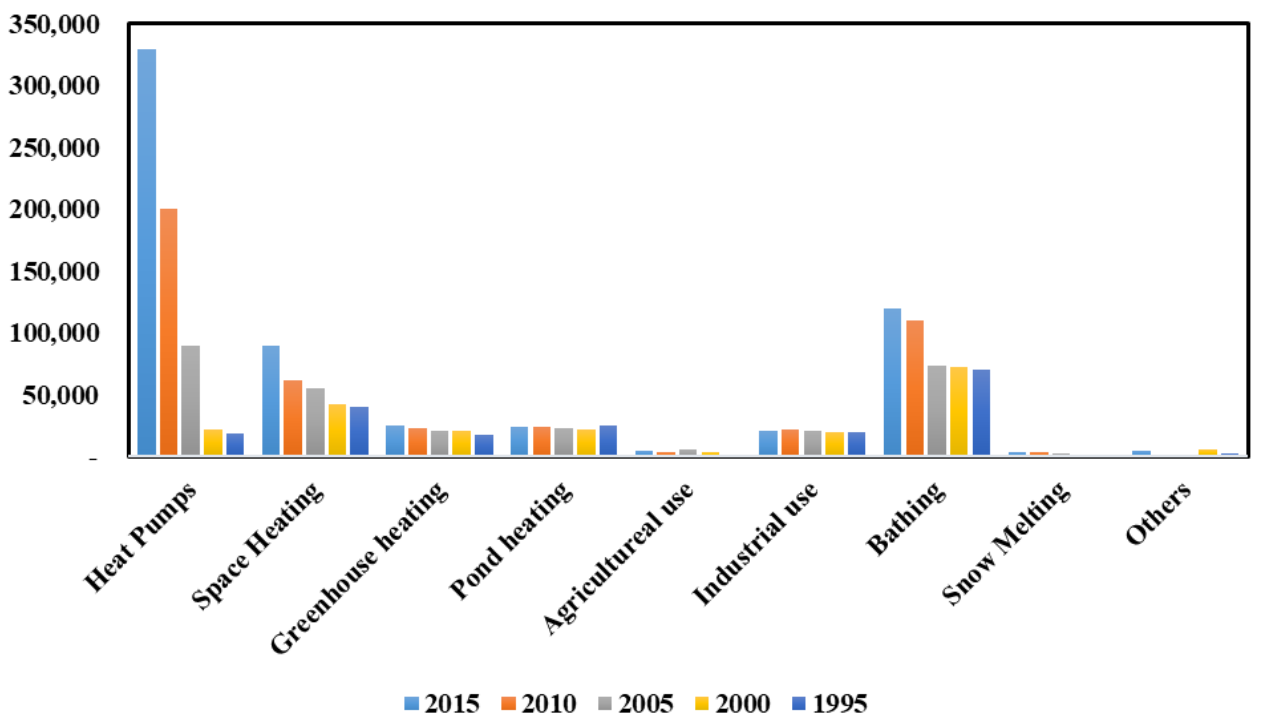

Fig. 7. Amount of geothermal energy used in different sectors from 1995 to 2015

In Figure 8, the amount of electricity generated by geothermal energy in the ten countries has been investigated and it has been proved that United States is the highest in using this energy [34]

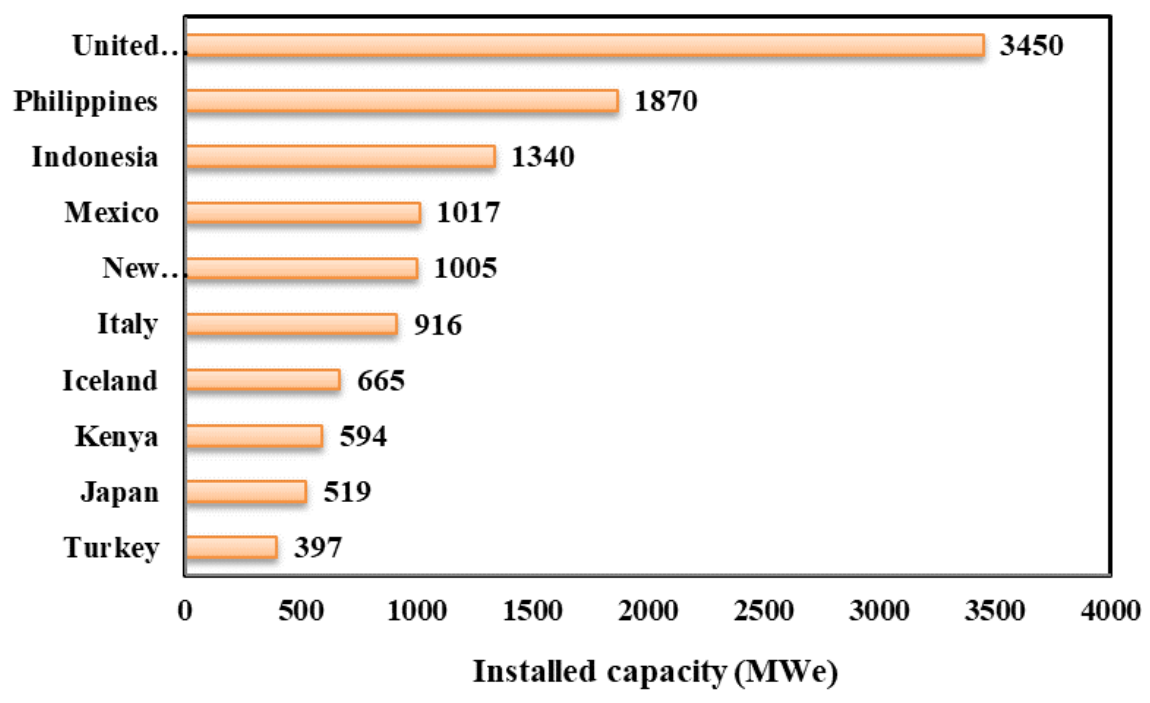

Fig. 8. Geothermal energy capacity in ten countries

\section{Geothermal Energy Capacities and History in Iran}

In Iran, since 1975, extensive studies have been initiated in order to identify the geothermal energy source potential of the Ministry of Energy in cooperation with ENEL Consulting Engineers in the north and northwest regions of Iran in an area of 260,000 square kilometers. The result of this research revealed that Sabalan, Damavand, Khoy, Mako and Sahand areas, with an area of more than 31,000 square kilometers, are suitable for further studies and geothermal energy utilization. In this regard, the exploration program, including geological, geophysical and geochemical studies, was planned. In the year 1982, with the completion of preliminary exploratory studies in each of the areas mentioned, the areas susceptible are more precisely identified and as a result, in the Sabalan area: Meshkin shahr, Sarein and Busheli areas, in the Damavand area of the district: Neunal, in the Maku- Khoy regions: Black and Dasht and in the Sahand area, five smaller regions were selected to focus on the activities of the exploratory phase. After 
a relatively long interruption and with the aim of reactivating the plan, existing reports were revisited by UNDP experts in 1991 and the Meshkin Shahr geothermal region was introduced as the first priority for further exploratory studies [35].

Following the mentioned studies, exploration, injection and descriptive drilling projects were defined in order to identify more potential in the Sarein area of Meshkin Shahr in 2002 that drilling operations are the first geothermal wells in the same year began. The first phase of this project was completed in 2004. In total, three exploratory wells and two injection well bars were drilled at this stage and two-loop test of three exploratory wells was successfully carried out, which was the most important achievement of this phase of the project to acquire the know-how in geothermal wells. The second phase of the project began in 2005. In Figure 9 , areas with geothermal energy are shown.

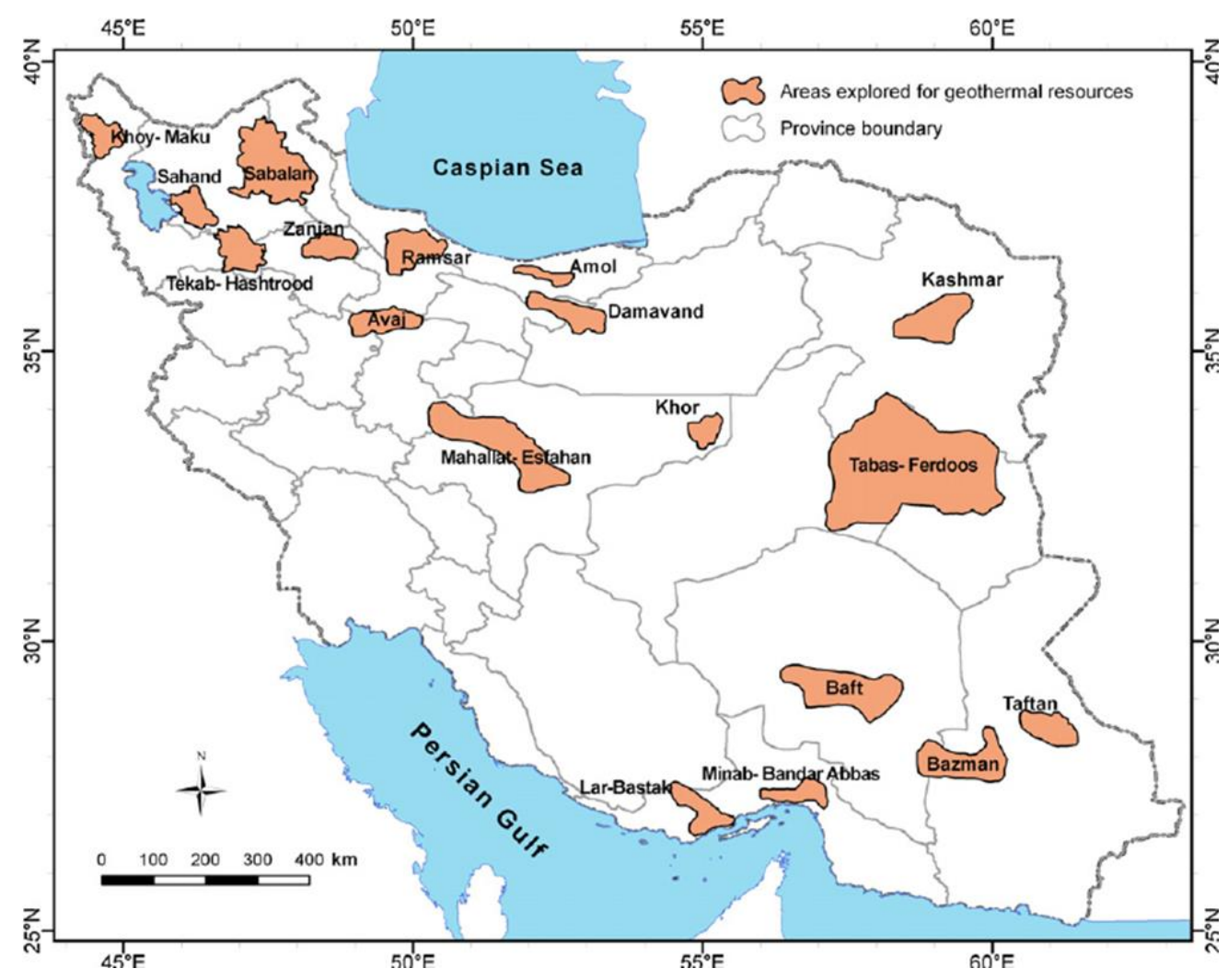

Fig. 9. Geothermal potential areas in Iran

In the project for the development of the geothermal field and the construction of Meshkin Shahr Power Plant, the drilling of wells, the operation of wells during the test period and the manufacture of test equipment in the country have been completely indigenous and were done by local experts.

Also, in the field of using geothermal heat pumps, $t$ so far, the technology of installing earth coils has been completely and $100 \%$ native in Iran n. [36] Figure 10 shows the distribution of geothermal energy in Iran, according to the figure, it can be stated that geothermal energy can be used in three parts of the northwest, center of Iran and south of Iran. Of course, in the northwest of Iran due to the presence of volcanoes and in the center of Iran due to the presence of the desert, and in southern Iran, the use of this energy can be very useful due to the Persian Gulf Sea. 


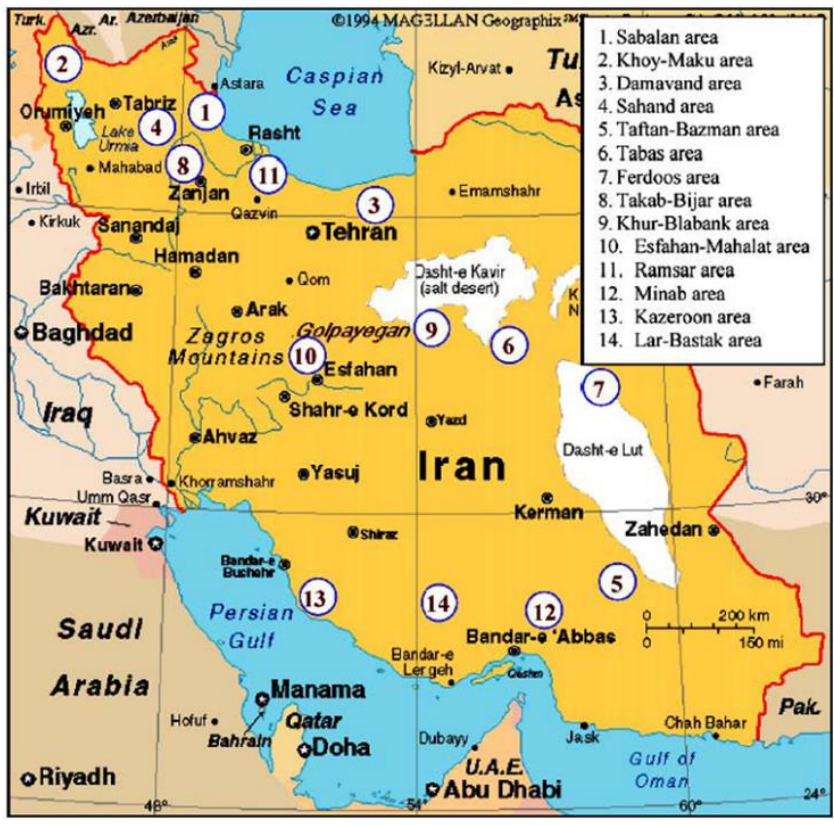

Fig. 10. Distribution of geothermal potential in different regions of Iran for review

\section{Iran Geothermal Power Plant}

\section{A. Meshkin Shahr - brief history}

The Meshkin Shahr geothermal prospect lies in the Moil valley on the western slopes of Mt. Sabalan, approximately $16 \mathrm{~km}$ SE of Meshkin Shahr City. Mt. Sabalan was previously explored for geothermal resources in 1974, with geological, geochemical, and geophysical surveys being undertaken. Renewed interest in the area resulted in further geophysical, geochemical and geological surveys being carried out in 1998. These studies have resulted in the identification of a number of prospects associated with Mt. Sabalan. The present study has been undertaken to find out what information is needed to establish baseline environmental conditions involving surveys of geology and land, weather conditions, noise conditions, ecology and socio-economic conditions [36].

\section{B. Meshkin Shahr Power Plant}

Meshkin Shahr Power Plant (Ardabil province, near Meshkin Shahr city) is one of Iran's geothermal plants with a production capacity of $55 \mathrm{MW}$. In this power plant, the water is injected through the pipe and by 250 to 500 degrees Celsius, the water is turned into steam, then the steam comes to the surface and the steam turbine circulates [37]. Based on studies by the Office of the New Energy Organization of Iran, the
Meshkin Shahr area is the best point for using the geothermal energy capacity in the country. So that the main purpose of this office is to build and operate a $100 \mathrm{MW}$ nominal power plant in the area. According to studies, Sabalan's domains in Meshkin Shahr have the capacity to build up to 400 megawatts of power plants [38]. According to the studies of the power plant of the Energy Office, the first exploration well of Meshkin Shahr was erected vertically in 2002 with a depth of 3,200 meters and a temperature of 250 degrees Celsius. The second exploratory well was drilled in 2004 to a depth of 3,177 meters with a 140degree cavity at the end of the well, and then the third exploratory well at a depth of 2,695 meters and a temperature of 211 degrees Celsius was drilled. The 17 wells forecast for this plant, so far, 11 wells have been drilled and three wells have successfully passed the steam outlet test stage [39]. Table 2 shows the characteristics of this power plant.

Table 2. Geothermal Power Station at Meshkin Shahr

\begin{tabular}{|c|c|}
\hline \multicolumn{2}{|c|}{ Power plant specifications } \\
\hline Founding date & 1377 \\
\hline Type of power plant & geothermal \\
\hline $\begin{array}{c}\text { The number of } \\
\text { geothermal wells }\end{array}$ & 17 \\
\hline Deep geothermal wells & More than 2, 000 meters \\
\hline Condition & active \\
\hline The owner & $\begin{array}{c}\text { New Energy Organization } \\
\text { of Iran (SANA) }\end{array}$ \\
\hline Maximum power & $400 \mathrm{Mw}$ \\
\hline power & $100 \mathrm{Mw}$ \\
\hline
\end{tabular}

\section{Sabalan geothermal power plant}

Northern slopes of Sabalan hosts many hot springs (seven in the Mouil Valle near Meshkin Shahr, one further west at Yel Sou, and three aligned along majo NE trending structure near Ghotur-Suii). The temperatures of these thermal springs range from $21^{\circ} \mathrm{C}$ to $82^{\circ} \mathrm{C}$. Chemically they fall into different types including neutral, $\mathrm{Cl}-\mathrm{SO} 4$ and acid SO4. Giggenbach [40] (1992) analyzed the hot springs waters and found relatively low $\mathrm{Na}-\mathrm{K}-\mathrm{Mg}$ temperatures of about $150^{\circ} \mathrm{C}$. Mt. Sabalan lies on the South Caspian plate, which underthrusts the Eurasian plate to the north. It is in turn under thrust by Iranian plate, which produces compression in a northwest direction. This is complicated by a dextral rotational movement caused by northward under thrusting of the nearby Arabian plate beneath the Iranian plate. There is no BenioffWadati zone to indicate any present day subduction. 
Mt. Sabalan is a Quaternary volcanic complex that rises to a height of $4811 \mathrm{~m}$, some $3800 \mathrm{~m}$ above the Ahar Chai valley to the north. Volcanism within the Sabalan caldera has formed three major volcanic peaks which rise to elevations of around $4700 \mathrm{~m}[41]$.

Analysis of the single-flash geothermal power plant was conducted using energy and exergy concepts for Sabalan, Iran. Reservoir fluid enthalpy and mass flow rate are $1000 \mathrm{~kJ} / \mathrm{kg}$ and $500 \mathrm{~kg} / \mathrm{s}$ respectively. EES software was used to model the plant. Optimization was done to maximize the net power output of the plant. Optimum pressure value for separation is 5.5 bar. With these optimum pressure values the net power output of the plant is calculated to be 36594 $\mathrm{KW}_{\mathrm{e}}$. Pumps and compressor will use $843 \mathrm{KW}_{\mathrm{e}}$ and
$3350 \mathrm{KW}$, respectively. Table 2 illustrates important parameters at major stages of power plant at optimal pressure. The overall first and second law efficiencies of the power plant are $7.32 \%$ and $32.73 \%$, respectively. The reference conditions for exergy analysis are $15^{\circ} \mathrm{C}$ and atmospheric pressure. Figure 11 shows exergy destruction at different stages of the plant. $1.38 \%$ of the total exergy destruction is due to transmission from the reservoir to wellhead. $1.09 \%$ of the exergy is destroyed at the separation step. $4.91 \%$ is lost at the steam expansion unit. $23.35 \%$ are destroyed in the condenser. $13.19 \%$ and $41.44 \%$ are the waste brine from condensing steam and separator, respectively. Finally, the remainder is $32.73 \%$, which is the fraction of the initial exergy that the plant turns to power [42] .

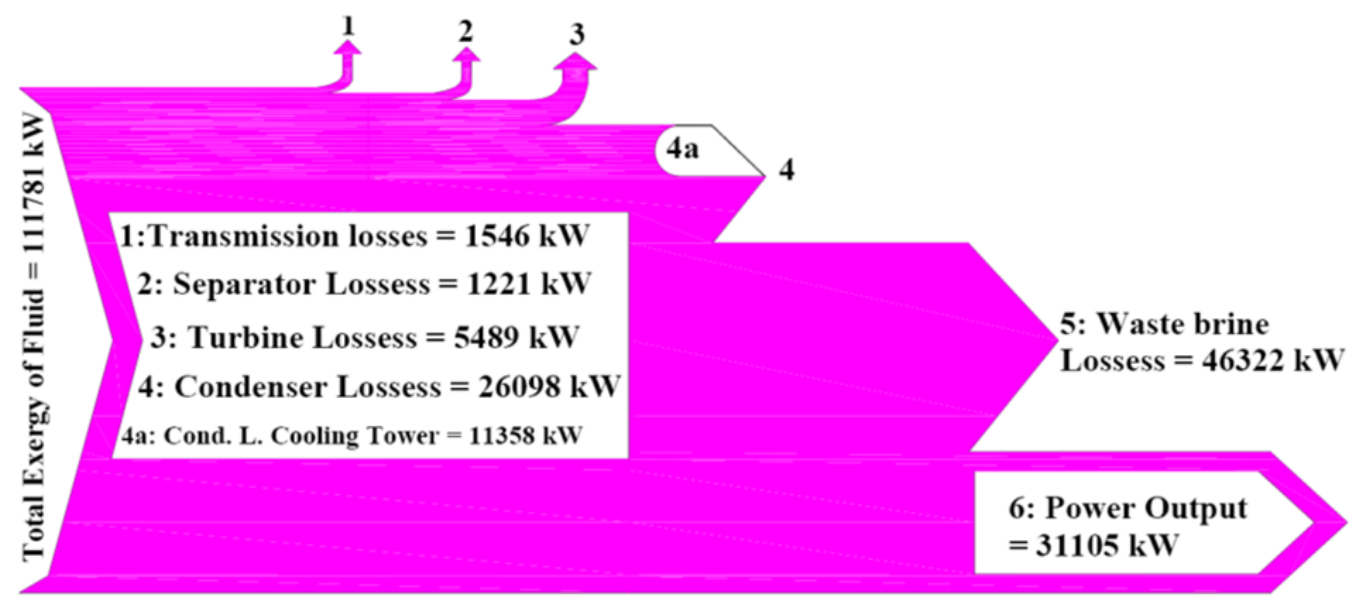

Fig. 11. Grassman presentation of the overall exergy flow

\section{Resources and Geothermal Maps in Iran}

The position of Iran in the tectonic boundaries shows the enormous power of the country's framework [43]. The continental plate of Saudi Arabia and the Indian Ocean plate have, on the other hand, caused major deformations in Iran and Zagros region Wrinkle is the evidence of the huge surface of these forces. Being placed in a volcanic belt has made Iran's geopolitical area very active and high potential of geothermal energy and the presence of volcanic activity and abundant hot water sources are evidence of this claim. There is eothermal energy potential in the country, according to studies conducted in more than 10 areas that have been identified based on tectonic activity, hot springs, surface emergencies and other geological evidence. According to studies conducted in 1377 , these areas are as follows:
District of Sabalan, Meshkin Shahr, Sarein and Busheli - Damavand Region, Nandul Area - Maku Region, Black Area of Fountain - Khoy Region, Dorsal Region - Sahand Region - Taftan District, Bessman Nayband Region - Birjand Area, Ferdos - Takab Region, Hashtrood - Region Khor, Bayabanak Isfahan District, Localities - Ramsar District - Bandar Abbas Region, Minab - Boushehr District, Kazeroon and Lar Bastak Area.

According to the world classifications, Iran is in the group of countries with potential reserves for the production of heat from geothermal energy using cyclic evaporation and binaries (for a period of 30 years) and the ability to generate electricity from geothermal energy with a capacity of more than 200 megawatts. 
Table 3 shows the geothermal energy potential $(\mathrm{kJ})$ in the Iranian provinces, which is the highest value for West Azarbaijan.

Table 3. Geothermal Energy Potentiometric Estimation (KJ) in Iranian Provinces

\begin{tabular}{|c|c|c|c|c|}
\hline thermal energy $(\mathrm{KJ})$ & $\begin{array}{l}\text { Number of possible } \\
\text { geothermal areas }\end{array}$ & $\begin{array}{c}\text { The approximate } \\
\text { number of hot springs }\end{array}$ & province name & $\mathrm{R}$ \\
\hline $58 \times 10^{16}$ & 7 & 15 & Azarbayjan sharghi & 1 \\
\hline $74 \times 10^{16}$ & 10 & 41 & Azarbayjan gharbi & 2 \\
\hline $44.4 \times 10^{16}$ & 6 & 50 & Ardebil & 3 \\
\hline $29.6 \times 10^{16}$ & 4 & 6 & Esfehan & 4 \\
\hline $7.4 \times 10^{16}$ & 1 & 2 & Ilam & 5 \\
\hline $22.2 \times 10^{16}$ & 3 & 3 & Bosher & 6 \\
\hline ------- & ------- & ------- & Tehran & 7 \\
\hline $7.4 \times 10^{16}$ & 1 & 1 & Chaharmahl va bakhtiyari & 8 \\
\hline $7.4 \times 10^{16}$ & 1 & 1 & Khorasan jonobi & 9 \\
\hline $22.2 \times 10^{16}$ & 3 & 3 & Khorasan razavi & 10 \\
\hline $22.2 \times 10^{16}$ & 3 & 3 & Khorasan shomali & 11 \\
\hline ------- & ------- & ------- & Khuzestan & 12 \\
\hline $22.2 \times 10^{16}$ & 3 & 3 & Zanjan & 13 \\
\hline $7.4 \times 10^{16}$ & 1 & 1 & Semnan & 14 \\
\hline $37 \times 10^{16}$ & 5 & 10 & Sistan va balochestan & 15 \\
\hline $22.2 \times 10^{16}$ & 3 & 3 & Fars & 16 \\
\hline $29.6 \times 10^{16}$ & 4 & 4 & Ghazvin & 17 \\
\hline |------ & $\begin{array}{l}------ \\
\end{array}$ & $\begin{array}{ll}------- \\
\end{array}$ & Ghom & 18 \\
\hline ב------ & ------- & ------- & Kordestan & 19 \\
\hline $59.2 \times 10^{16}$ & 8 & 9 & Kerman & 20 \\
\hline $14.8 \times 10^{16}$ & 2 & 2 & Kermanshah & 21 \\
\hline $7.4 \times 10^{16}$ & 1 & 1 & Kohkeloye va boyer ahmad & 22 \\
\hline $7.4 \times 10^{16}$ & 1 & 1 & Golestan & 23 \\
\hline $14.8 \times 10^{16}$ & 2 & 2 & Gilan & 24 \\
\hline $14.8 \times 10^{16}$ & 2 & 2 & Lorestan & 25 \\
\hline $37 \times 10^{16}$ & 5 & 5 & Mazandaran & 26 \\
\hline $7.4 \times 10^{16}$ & 1 & 6 & Markazi & 27 \\
\hline $103.6 \times 10^{16}$ & 14 & 16 & Hormozgan & 28 \\
\hline -------- & -------- & ------- & Hamedan & 29 \\
\hline $7.4 \times 10^{16}$ & 1 & 1 & Yazd & 30 \\
\hline -ב----- & ------- & ------- & Alborz & 31 \\
\hline $1.087 \times 10^{19}$ & 147 & 191 & Total & \\
\hline
\end{tabular}

\section{SUMMARY AND CONCLUSIONS}

Iran has more than 200 fossil fuel power plants which produce about 26,000 megawatts of electricity. According to the results, geothermal energy can generate about 100 megawatts of electricity. Also, with the introduction of different regions of Iran and using these energies, electricity production can be increased. Given that fossil fuel consumption in Iran is very high, Pollution in Iran is higher than the global level. However, with the use of geothermal energy, these contaminations can be reduced. Also, surveys on geothermal energy in 18 regions of Iran have suggested the largest areas of Tabas, Mahallat and Sabalan for the use of geothermal energy. 


\section{REFERENCES}

[1] M. Abedi , A. Afshar , V. Ardestani , G. Norouzi and C. Lucas ."Application of various methods for 2D inverse modeling of residual gravity anomalies." Acta Geophysica, vol. 58, pp. 317336 2010, doi:10.2478/s11600-009-0053-2.

[2] A. Mollahosseini, S.A. Hosseini, M. Jabbari, A. Figoliand A. Rahimpour. "Renewable energy management and market in Iran: A holistic review on current state and future demands." Renewable and Sustainable Energy Reviews, vol. $\quad 80, \quad$ pp. 774-88, 2017, doi:10.1016/j.rser.2017.05.236.

[3] A.A. Soltaniehand M. Rezaeian. "Nuclear and renewable energy in Iran: Nuclear challenges and opportunities." International Journal of Hydrogen Energy, pp.2-6, 2016, doi:10.1016/j.ijhydene.2017.02.075.

[4] S. Fathi and A.M. Lavasani. "A Review of Renewable and Sustainable Energy Potential and Assessment of Solar Projects in Iran." Journal of Clean Energy Technologies,vol. 5, pp.126-30, 2017 , doi:10.18178/JOCET.2017.5.2.356.

[5] A.H. Ghorashi and A. Rahimi. "Renewable and non-renewable energy status in Iran: Art of know-how and technology-gaps." Renewable and Sustainable Energy Reviews, vol. 15, pp. 729-36, 2011, doi:10.1016/j.rser.2010.09.037.

[6] M.K. Dehkordi, H. Kohestani, H. Yadavar, R. Roshandel and M. Karbasioun. Implementing Conceptual Model Using Renewable Energies in Rural Area of Iran. Information Processing in Agriculture, vol. 4 , pp. 228-240. 2017, doi:10.1016/j.inpa.2017.02.003.

[7] D. Khojasteh, D. Khojasteh, R. Kamali, A. Beyene and G. Iglesias. "Assessment of renewable energy resources in Iran with a focus on wave and tidal energy." Renewable and Sustainable Energy Reviews, vol,??, pp. 0-1, 2017, doi:10.1016/j.rser.2017.06.110.

[8] U. B. Akuru, I.E. Onukwube, I.O. Okoro and E.S. Obe. "Towards $100 \%$ renewable energy in Nigeria." Renewable and Sustainable Energy
Reviews , vol. 71, pp. 943-53, 2017, doi:10.1016/j.rser.2016.12.123.

[9] G. Wynn. "Fossil fuel subsidies to fall further." Available:http://energyandcarbon.com/cutsfossil-fuel-subsid [date, 2015].

[10] M. Vahedi Torshizi and A. Hoseini Mighani.

"The application of solar energy in agricultural systems." Renewable Energy and Sustainable Development, vol. 3, pp. 234-40, 2017, doi:10.21622/resd.2017.03.2.234.

[11] H. Kariminiya and F. Farhadi. "Simulation and technical review of absorption chiller system Single effect of lithium bromide water with solar energy." Journal of Chemistry and Chemical Engineering of Iran, vol. 33 pp. 53-64, 2014.

[12] M. Saki pour, A.K. Nejadian, S. Jou and S.A.A. Jafarymosavy??. "Potential of solar energy use and reducing greenhouse gases emissions in Ahvaz." Jundishapur Journal of Health Sciences, vol. 4, pp. 1-10, 2012.

[13] A. Mohammadi, S. Rafiee, A. Jafari, A. Keyhani, S.H. Mousavi-Avval and S. Nonhebel . "Energy use efficiency and greenhouse gas emissions of farming systems in north Iran." Renewable and Sustainable Energy Reviews,vol. 30, pp. 724-33, 2014, doi:10.1016/j.rser.2013.11.012.

[14] Climate Disruption \& Adaptation. Available http://www.sustainablesanmateo.org/home/indica tors/climate-disruption-adaptation/ ; [date, 2016].

[15] S. Mirmohamadsadeghi, K. Karimi, A. Zamani, H. Amiri and I.S. Horváth . "Enhanced solid-state biogas production from lignocellulosic biomass by organosolv pretreatment." BioMed Research International, vol. 2014, article ID 350414, 6 pages; doi:10.1155/2014/350414.

[16] Z. Farahani, S. Ahmadi and S. Dehyouri. "Factors affecting the use of solar energy technology in agriculture from the perspective of Iranian agricultural experts." Journal title, vol. 10,pp. 581-5, 2015

[17] Iran. Available :https://energy.fanack.com/iran [date, 2017]. 
[18] H.S. Fami , J. Ghasemi, R. Malekipoor, P. Rashidi, S. Nazari and A. Mirzaee A. "Renewable energy use in smallholder farming systems: A case study in tafresh township of Iran." Sustainability, vol. 2,pp. 702-16, 2010, doi:10.3390/su2030702.

[19] A. Mostafaeipour and H. Abarghooei. "Harnessing wind energy at Manjil area located in north of Iran." Renewable and Sustainable Energy Reviews, vol. 12, pp. 1758-66, 2008, doi:10.1016/j.rser.2007.01.029.

[20] S.H. Kulkarni, T.R. Anil and R.D. Gowdar . Wind Energy Development in India and a Methodology for Evaluating Performance of Wind Farm Clusters. Journal of Renewable Energy, vol. 201, pp1-11, 2016.

[21] E. Bonamente, L. Pelliccia, M.C. Merico , S. Rinaldi, A. Petrozzi and C. Centro. The Multifunctional Environmental Energy Tower: Carbon Footprint and Land Use Analysis of an Integrated Renewable Energy Plant, Sustainability, vol. 7, pp. 13564-84, 2015, doi:10.3390/su71013564.

[22] N. Afsharzade, A. Papzan, M. Ashjaee, S. Delangizan, S. van Passel and $\mathrm{H}$. Azadi . "Renewable energy development in rural areas of Iran." Renewable and Sustainable Energy Reviews, vol. 65, pp. 743-55, 2016, doi:10.1016/j.rser.2016.07.042.

[23] J.W. Lundand T.L. Boyd. "Direct utilization of geothermal energy 2015 worldwide review." Geothermics, vol. 60, pp.66-93. 2016, doi:10.1016/j.geothermics.2015.11.004.

[24] A. Ragnarsson. "Geothermal development in Iceland," in Proceedings World Geothermal Congress 2015, pp.19-25.

[25] Y. Noorollahi, H. Yousefi, R. Itoiand S. Ehara. "Geothermal energy resources and development in Iran." Renewable and Sustainable Energy Reviews, vol. 13, pp.1127-32, doi:10.1016/j.rser.2008.05.004.

[26] S. Porkhial and P. Yousefi. "Geothermal energy in Iran Soheil." in World Geothermal Congress, 2015, pp. 25-9.
[27] Y. Noorollahi Y, R. Itoi, H. Fujii and T. Tanaka T. Geothermal Resources Exploration and Wellsite Selection with Environmental Consideration Using GIS in Sablan Geothermal Area. PROCEEDINGS, Thirty-Second Workshop on Geothermal Reservoir Engineering, 2007.

[28] S. Björnsson. Geothermal development and research in Iceland. place of publication, publisher, 2012.

[29] I.B. Fridleifsson. "Geothermal energy for the bene $\mathrm{t}$ of the people." Renewable and Sustainable Energy Reviews, vol. 5, pp. 299312, 2001.

[30] U. Younas, B. Khan, S.M. Ali, C.M. Arshad, U. Farid and K. Zeb, et al. "Pakistan geothermal renewable energy potential for electric power generation: A survey." Renewable and Sustainable Energy Reviews, vol. 63, pp. 398413, 2016, doi:10.1016/j.rser.2016.04.038.

[31] P. Bayer, L. Rybach, P. Blum and R. Brauchler. "Review on life cycle environmental effects of geothermal power generation." Renewable and Sustainable Energy Reviews, vol. 26, pp. 44663, 2013, doi:10.1016/j.rser.2013.05.039.

[32] R.S. Atlasonand R. Unnthorsson. "Calculations of environmental benefits from using geothermal energy must include the rebound effect." Geothermics, vo. 66, pp. 151-5, 2017, doi:10.1016/j.geothermics.2016.12.002.

[33] H. Ganjehsarabi, I. Dincerand A. Gungor . "Exergy analysis and environmental impact assessment of a geothermal power plant," in Causes, Impacts and Solutions to Global Warming, book section 2013, pp. 825-837, doi:10.1007/978-1-4614-7588-0.

[34] J. Zhu, K. Hu, X. Lu, X. Huang, K. Liu and X. Wu. "A review of geothermal energy resources, development, and applications in China: Current status and prospects." Energy, vol. 93, pp. 46683, 2015, doi:10.1016/j.energy.2015.08.098.

[35] "Geothermal energy history in Iran." Renewable Energy and Energy Efficiency Organization. Available: http://www.satba.gov.ir/fa/geothermal/introandhis t [date, 2017]. 
[36] Y. Noorollahiand H. Yousefi. "Preliminary environmental impact assessment of a geothermal project in Meshkinshahr, NW-Iran." International Geothermal Conference, Reykjavik, 2011, pp.25-9.

[37] A. Saffarzadeh, S. Porkhialand M. Taghaddosi. "Geothermal energy developments in Iran," Proceedings in World Geothermal Congress, 2010, pp. 25-9.

[38] "Iran builds Mideast's first geothermal plant." The Chamber of Commerce and Industry Brazil-Iran 2017.

Available: http://camiranbrasil.com.br/noticias/energia/ira-c [date, 2017].

[39] A. Yousefi-Sahzabi, K. Sasaki, H. Yousefi, S. Pirastehand Y. Sugai Y. "GIS aided prediction of $\mathrm{CO} 2$ emission dispersion from geothermal electricity production." Journal of Cleaner Production, vol. 19, pp.1982-93, 2011, doi:10.1016/j.jclepro.2011.06.009.
[40] W.F. Giggenbach. "Geothermal solute equilibria. Derivation of Na-K-Mg-Ca geoindicators." Geochimica et Cosmochimica Acta, vol. 52, pp. 2749-65, 1988, doi:10.1016/00167037(88)90143-3.

[41] S. Porkhial, MM. Ghomshei and P. Yousefi. "Geothermal energy in Iran," in Proceedings World Geothermal Congress, 2010, pp. 25-9.

[42] S. Jalilinasrabady, R. Itoi, H. Fujii T. Tanaka. "Energy and exergy analysis of Sabalan geothermal power plant, IRAN," in Proceedings, World Geothermal Congress, 2010, pp. 25-9.

[43] M. Mohammadzadeh-Moghaddam, B. Oskooi, M. Mirzaei and S.J. Jouneghani. "Magnetic studies for geothermal exploration in Mahallat, Iran," Istanbul 2012 - International Geophysical Conference and Oil \&amp; Gas Exhibition, Society of Exploration Geophysicists and the Chamber of Geophysical Engineers of Turkey, 2012, pp. 1-4, doi:10.1190/IST092012-001.62. 